\title{
Leadership as Important Factor for Agricultural Development in Albania
}

Rezear Kolaj

Dorjana Zahoaliaj

Etleva Dashi

Faculty of Economics and Agribusiness, Agricultural University of Tirana, Tirana

Dubravka Skunca

Faculty of Business and Industrial Management, "Union-Nikola Tesla" University, Belgrade

\begin{abstract}
An important challenge for the development of the Albanian agriculture remains the small surface and farm fragmentation. A chance for enhance with a sustainable impact is the agriculture development based on the principles of collective action. The objective of the study is measurement of the importance of leadership perceived by farmers and farmers' willingness to cooperate among main agricultural activities in Albania. The study will investigate farmers in two important agricultural sectors - vegetable production in greenhouses and apple production. Study measures the impact of leadership as a factor which increases farmers' potential for collective action, illustrated by vegetable producers in greenhouses and apple producers. Results of the research show that leadership is an important factor for development of collective action in Albanian agriculture. The results are especially important for agricultural sectors of vegetable production in greenhouses and apple production, but they can also be useful for undeveloped agricultural regions. Promotion of leadership in farming communities will have benefits beyond agriculture by promoting good management and maintenance of common resources.
\end{abstract}

Keywords: collective action, greenhouse vegetable producers, apple producers, community

\section{Introduction}

During the past 20 years, Albania has transformed from an agricultural oriented economy to a service oriented economy. However, the high mobility of workforce within and outside the country has created a number of issues in the area of employment, land and capital associated with the use of resources. Due to these developments new urban centres have developed. However, the national fund of farmland has been reduced and irrigation and drainage canals were damaged, hence hampering even more the farming activities. Consequently, in some rural areas with deteriorating features and lack of resources, the unemployment and the overall migration indicators has been increased. The development of agriculture would reduce these effects and it would have sustainable impact. But the development of agriculture in Albania faces the problem of consolidation of agricultural farms. The consolidation would be an opportunity to simultaneously increase agricultural production and access to the market, which would fulfil the main objective of the farmers - maximization of the profit. Given the small size of the farms this is still a challenge. Albania has approximately 350000 farms, with size ranges between 1 and 1.2 ha. Structurally, the farms are quite fragmented as the pieces of land, even of the same family members, are not connected to each other.

Farm size has grown very slowly from 1.04 ha to 1.2 ha in year 2000. Land fragmentation combined with small farm size represents the structural problem which is resulting in low competitiveness of the sector (Skreli and McCalla 2013) (Skreli et al. 2011). Important alternative for overcoming this structural problem is cooperation among farmers based on principles of collective action (Kola et al. 2014). Interdisciplinarity of the collective action is represented in an extensive literature sources (Olson 2002, Agrawal et al. 2009; Ostrom and Ahn 2007; Kurosaki 2005; Ostrom 2003; McCarthy et al. 2002; Meinzen-Dick et al. 2002; Johnson 2000; Baland and Platteau 1997; White and Runge 1994). 
Olson believes that the development of relations at individual level or on a group basis simply by following the general theory upon which the logic of collective action is based including factors such as the personal and public interests, the leadership from rationality or the impact of emotional nature, not only cannot be too simple - but in special cases can perhaps be even completely impossible (Olson 2002). Ostrom and Ahn have an opinion that political and economic performance of companies based in rural areas depends critically on the way how the community members are solving the problem of collective action (Ostrom and Ahn 2007).

Moreover, the issues of collective action and cooperative agriculture face a particularly complicated problem in Albania. However, because of the small farm size and land fragmentation, farmers encounter many difficulties while improving technology at the farm level, providing inputs, selling their farm products and facing unfair competition from input suppliers and traders. Hence, there is no better alternative than cooperation among farmers (Skreli et al. 2011).

The asymmetry of information, limited sanctions, enforcement mechanisms and lack of monitoring create conditions through which the opportunistic behavior can dominate. Banaszak explained that the same forms of cooperation in collective action in the similar environment can bring different results (Banaszak 2008). The question is why certain cooperation agreements on agricultural markets are successful, while others are not. The main purpose of these agreements is to organize joint sale of products that were individually produced by the members of the agreement. Some of the groups of producers are effective, while others are not. Banaszak states that variables such as the strength of leadership, previous knowledge in the field of business, the initial selection of members and the number of members have a significant positive impact on the chances of success in the analyzed groups of producers (Banaszak 2008).

For the promotion and the development of collective action economic and social factors, such as the level of wealth or farmland size, income and employment, as well as human and social capital, are crucial. Krishna says that there are communities that are more cooperative, where members care for each other and are prepared to act collectively for a common purpose, while in other communities there is internal war, disagreements, jealousy and selfishness (Krishna 2004). The concept of social capital has the focus on these differences in groups as they influence the results that the group can achieve in practice. Krishna raises the logical question, which is why a certain community has a higher profit when it has the same program as the other, especially when the two communities receive the same overall level of resources (Krishna 2004). A number of different reasons, such as quality of leadership and effectiveness of the human resources, can explain the observed differences. Leadership in this context represents a defining factor that goes beyond agriculture. The quality of decision making in farming communities is directly related to the use of resources in rural areas.

This study will examine importance of leadership as a determining factor for stimulation of collective action for farmers in two important and growing agricultural sectors in Albania - vegetables production in greenhouses and apple production.

\section{MATERIALS AND METHODS}

\section{Vegetables producers in greenhouses - case study I}

Vegetable production in greenhouses has become one of the most important export activities for Albanian agriculture. The export of vegetables from greenhouses has increased 9 times between the year 2001 and 2011 (UN ComTrade, 2013). With a rather high labor to land ratio of Albanian agriculture, labor intensive industries are economically justified alternative (Skreli and McCalla 2013). Leadership is an important determinant for cooperation. Banaszak (2008) summarizes the relevant studies with regards to the role of leadership for cooperation from the perspective of game theory and states that in coordinated games, leaders economize the choice by one of multiple balances and in social dilemma games the leadership increases the levels of individual contributions giving an example to the other players and changing the profit structure by introducing penalties for free-riding (Banaszak 2008). The determinants of collective action are grouped into players' and environmental characteristics. Environmental characteristics are measured as perceived by individual producers, which are farmers represented as players. Socio-demographic profile of the sample is given in the Table 1.

Table 1. Socio-demographic profile of the sample ( $\mathrm{N}=200$, frequency, percentage in brackets)

\begin{tabular}{|c|c|c|c|c|c|c|c|c|}
\hline \multirow[t]{2}{*}{ Country } & \multicolumn{3}{|c|}{ Gender } & \multicolumn{2}{|c|}{ Age (years) } & \multirow[b]{2}{*}{$35-49$} & \multirow[b]{2}{*}{$50-64$} & \multirow[b]{2}{*}{$\geq 65$} \\
\hline & $\mathrm{N}(\%)$ & Female & Male & $\leq 24$ & $25-34$ & & & \\
\hline
\end{tabular}




\begin{tabular}{|c|c|c|c|c|c|c|c|c|}
\hline Albania & $\begin{array}{l}200 \\
(100)\end{array}$ & $\begin{array}{l}15 \\
(7.5)\end{array}$ & $\begin{array}{l}185(92 . \\
5)\end{array}$ & $0(0)$ & $5(2.5)$ & $130(65)$ & $64(32)$ & $1(0.5)$ \\
\hline
\end{tabular}

Source: Own calculations

Hypothesis: Farmers' perception over leadership presence increases the chances over collaborative actions.

The questionnaire is constructed to measure several variables. The data are collected through a survey of 200 questionnaires. The choice method is based on random selection. The sample of 200 respondents is considered sufficient to ensure a precision level of 7\% and a confidence level of 95\% (Israel 2012).

Perception on leadership is measured by the dummy variable.

Given the fact that the dependent variable is a quality variable dummy, to assess the determinants of collective actions in the case of the vegetables producers in greenhouses the binary logistic model is used. This model uses the maximum likelihood estimation for assessing the parameters of the regression equation.

Binary logistic model can be described by the following equation:

$$
\ln \left(\frac{p}{1-p}\right)=a+b_{i} x_{i}+c_{i} z_{i}+e
$$

Where $\mathrm{P}_{\mathrm{i}}$, is the probability that a person participates in a collective action; $1-\mathrm{P}_{\mathrm{i}}$ is the probability that a person does not participate in a collective action; $a$ is a constant; $x_{i}$ and $z_{i}$, are respectively the variables that represent the characteristics of individual players and the perception of players for the environment and $b_{i}$ and $c_{i}$ are vector parameters to be measured. The equation is:

$$
\frac{P}{1-P}=e^{a+b_{i} x_{i}+c_{i} z_{1}}
$$

The change of one unit in the stock of social capital leads to an increase $e^{b 1}$ of the chances that the farmer will participate in collective action, against the probability that the farmer won't participate. Binary logistic regressive model is preferred against the linear probability model, binomial or multinomial. Other regression models assume that the marginal effect of independent variables over the dependent variables is constant for different levels of the independent variables. Since we have no evidence that this may be a case, the regressive logistic model comes as a solution, because it does not include this assumption. Regarding the possible marginal effects, we may say that linear regressive model is just a special case of the logistic model.

Based on the model results, leader has a strong influence on farmers to undertake collective actions in greenhouses in Albania. Leadership ratio $(4,166)$ shows that farmers are 4 times more likely to cooperate than not to cooperate if there is a reliable and competent leader among them.

\section{Apple producers - case study II}

The apple production is important for Albanian agriculture. The production of apples in Albania has grown from 12. 000 to 54. 000 tons from the year 2000 to 2010 (FAOSTAT 2010) and from the demand point of view, the expenses for apple consumption are the highest (FAOSTAT 2010). A number of studies (Meinzen Dick-et al. 2002; Kurosaki, 2005; Banaszak 2008) identify leadership as an influential factor in the decision-making connected to collective action in farming community. Other authors (Skreli et al. 2011) have found a positive impact of leadership on the collective action in Albania. In the last two decades farmers have experienced role of leadership and learned whom to trust and whom not. Determinants of collective action are grouped to measure factors connected to farmer's perception. There are individual and environmental characteristics. The leadership is measured as part of environmental characteristics. Leadership is a dummy variable and it is taking the value 1 for farmer's perception on the presence of leadership and value 0 for farmer's perception that there is lack of leadership. Socio-demographic profile of the sample is given in the Table 2. 
Table 2. Socio-demographic profile of the sample ( $\mathrm{N}=220$, frequency, percentage in brackets)

\begin{tabular}{|c|c|c|c|c|c|c|c|c|}
\hline \multirow[t]{2}{*}{ Country } & \multicolumn{3}{|c|}{ Gender } & \multicolumn{5}{|c|}{ Age (years) } \\
\hline & $\mathrm{N}(\%)$ & Female & Male & $\leq 24$ & $25-34$ & $35-49$ & $50-64$ & $\geq 65$ \\
\hline Albania & $\begin{array}{l}220 \\
(100)\end{array}$ & $\begin{array}{l}20 \\
(9.1)\end{array}$ & $\begin{array}{l}200(90 . \\
9)\end{array}$ & $0(0)$ & $7(3.2)$ & $\begin{array}{l}141(64 . \\
1)\end{array}$ & $\begin{array}{l}69(31 . \\
4)\end{array}$ & $3(1.4)$ \\
\hline
\end{tabular}

Source: Own calculations

Hypothesis: The perception of farmers on the presence of leadership increases the opportunities for collective action.

The questionnaire was constructed in order to measure the factors and the leadership variable. The data are collected through a survey of 220 questionnaires. The choice method is based on random selection.

The econometric model that was build was the linear probability model, which transformed the average in a qualitative binary variable (dummy). The linear probability model, known as the method of least squares, is presented as follows:

$Y_{i}=a_{i} X_{i}+b_{i} Z_{i}+e$

Thus, the probability $\left(Y_{i}\right)$ is equal to the sum of two systematic factors $a_{i} X_{i}+b_{i} Z_{i}$ and $e$ is the error term. Moreover, $a_{i}$ is the coefficient before the individual's features $X_{i}$ that represents a partial probability, while $b_{i}$ is the coefficient before the environmental features $Z_{i}$.. Thus, summarizing, $a_{i} X_{i}$ include the individual characteristics and bi $Z_{i}$ the environmental features.

Results interpretation

Based on the model results, leader has a strong influence on farmers involved in apple production in Albania to undertake collective actions. With the presence of capable leader there is increase of approximately $19,3 \%$ of a possibility that farmers will participate in collective action.

\section{CONCLUSION}

In the both cases results show that variable leadership is a determinant factor for participation in collective action of farmers who are involved in vegetables production in greenhouses and farmers who are apple producers. Results for both case studies are also clear evidence that farmers' perception of good leadership in rural community increases the possibility of involving in collective action. The results are very important for production in greenhouses and production of apples, but also for other agricultural activities in terms of their development potential in the future.

The statistical significance of leadership suggests that development of economic factors and rapid growth, as illustrated in two case studies, can overcome the lack of confidence from the past between the members in the community, and provide opportunities. On the other hand, it can also contribute to the agricultural regions with lower index of development, encouraging and promoting a credible and competent leadership as a new option to improve the conditions for common actions while increasing initial forms of cooperation with reciprocal interest between members. This would help policymakers and public bodies, as well as agricultural business operators to better understand and address further investments.

The growth and strengthening of the role of leadership in the farming communities would also be useful for the promotion and development of agriculture. Furthermore, it would bring positive effects, such as raising awareness for degree of competence and quality of decision-making concerning the use of resources and rural development. The scale and intensity of the use of resources, such as land, forests and rivers for economic development and growth, implicates costs and requires quality of agricultural products.

\section{REFERENCES}

[1] Agrawal A., Kononen M., Perrin N. (2009): The Role of Local Institutions in Adaptation to Climate Change. Social Dimensions of Climate Change, 118: 1-23.

[2] Baland J. M., Platteau J. P. (1997): Wealth inequality and efficiency in the commons - Part I: The unregulated case. Oxford Economic Papers, 49: 415-482. 
[3] Banaszak I. (2008): Determinants of successful cooperation in agricultural markets: evidence from producers groups in Poland. Strategy and Governance of Networks, 1:27-46.

[4] FAOSTAT 2010 Available at http://faostat3. fao. org/home/E

[5] Israel G. D. (2012): Determining Sample Size. Available at http://www. psycholosphere. com/Determining\%20sample\%20size\%20by\%20Glen\%20lsrael. pdf (accessed Oct 10, 2016).

[6] Johnson J. D. (2000): Determinants of collective action on local commons: a model with evidence from Mexico. Journal of Development Economics, 62: 181-208.

[7] Kola R., Skreli E., Osmani M., Tanku A. (2014): Farmers' characteristics as determinants of collective action: the case of Greenhouse Producers in Albania. New Medit, 13: 20-27.

[8] Krishna A. (2004): Understanding, measuring and utilizing social capital: clarifying concepts and presenting a field application from India. Agricultural Systems, 82: 291-305.

[9] Kurosaki T. (2005): Determinants of Collective Action under Devolution Initiatives: The Case of Citizen Community Boards in Pakistan. The Pakistan Development Review, 44: 253-269.

[10] McCarthy N., Dutilly-Diané C., Drabo B. (2002): Cooperation, collective action in natural resource management in Burkina Faso: A methodological note. Available at http://www. capri. cgiar. org/pdf/capriwp27. pdf (accessed Sep 20, 2016).

[11] Meinzen-Dick R., Raju K. V., Gulati A. (2002): What affects organization and collective action for managing resources? Evidence from canal irrigation systems in India. World Development, 30: 649-666.

[12] Olson M. (2002): The Logic of Collective Action: Public Goods and the Theory of Groups. 20 ${ }^{\text {th }}$ Ed. Harvard University Press, Cambridge.

[13] Ostrom E. (2003): How Types of Goods and Property Rights Jointly Affect Collective Action. Journal of Theoretical Politics, 15: 239-270.

[14] Ostrom E., Ahn, T. K. (2007): The meaning of social capital and its link to collective action. Available at https://papers. ssrn. com/sol3/papers. cfm?abstract_id=1304823 (accessed Aug 25, 2016).

[15] Skreli E., Kola R., Osmani M. (2011): Factors determining collective action in Albanian agriculture: case of apple producers in Albania. Albanian Journal of Agricultural Sciences, 10: 35-41.

[16] Skreli E., McCalla A. (2013): Agricultural Markets in a Transitioning Economy: An Albanian Case Study. CPI Group, Croydon. 